NASA Technical Memorandum 106061

\title{
Texturing of InP Surfaces for Device Applications
}

Sheila G. Bailey

National Aeronautics and Space Administration

Lewis Research Center

Cleveland, Ohio

and

Navid S. Fatemi and Geoffrey A. Landis

Sverdrup Technology, Inc.

Lewis Research Center Group

Brook Park, Ohio

Prepared for the

1992 Spring Meeting of the Materials Research Society sponsored by the Materials Research Society

San Francisco, California, April 27-May 1, 1992 


\title{
TEXTURING OF InP SURFACES FOR DEVICE APPLICATIONS
}

\author{
Sheila G. Bailey \\ National Aeronautics and Space Administration \\ Lewis Research Center \\ Cleveland, Ohio 44135 \\ and \\ Navid S. Fatemi and Geoffrey A. Landis \\ Sverdrup Technology, Inc. \\ Lewis Research Center Group \\ Brook Park, Ohio 44142
}

\begin{abstract}
A unique process for texturing InP (100) wafers by anisotropic etching has been developed. The process produces irregular $\mathrm{V}$-grooves on the surface, which reduce the surface reflectivity. The process does not require photolithography or masking. The etching characteristics depend on doping, with etching tending to proceed more rapidly on the more heavily doped samples. Reduced reflectivity surfaces formed using this process can be applied to solar cells, photodetectors, and other optoelectronic devices.
\end{abstract}

\section{INTRODUCTION}

InP solar cells are highly radiation resistant and thus are a promising candidate for use in space. Solar cells based on InP may also be candidates for use in solar concentration systems for providing terrestrial electrical power. Indium phosphide is also used as a base material for optoelectronic devices including optical detectors, which are used for a wide variety of applications such as optical fiber communications.

Reduction of the surface reflection can increase the light absorption, and hence improve the efficiency, of solar cells, detectors, and optoelectronic devices. One way to decrease reflection is to form a "textured" surface, in which pyramids or grooves are formed on the surface so that light reflected from the surface makes a second pass for absorption. The process of anisotropic etching, where the etching rate varies strongly with the crystalline plane, can be used to form such surface structures. This process has been successfully used to decrease reflectance using pyramid-textured surfaces in silicon [1] and grooved surfaces in GaAs [2] solar cells.

\section{ANISOTROPIC ETCHING}

Texture etching techniques have been little used on indium phosphide solar cells to date, principally because anisotropic etching of III-V compounds is more complicated than on silicon. Since anisotropic etches distinguish between crystalline planes, surface texturing by anisotropic etching tends to produce pyramids in silicon [1], where the (111) and (11T) planes are identical, but tends to produce groove in compound semiconductors, where the (111) and (11T) planes are chemically different [3].

InP is a difficult material for anisotropic etching because the etching behavior is dependent on the doping type ( $\mathrm{p}$ or $\mathrm{n}$ ) and the dopant concentration. For anisotropic etching of InP we used the "Lewis" etchant, shown in Table 1 . Each component is precooled to $-20^{\circ} \mathrm{C}$ prior to mixing and carefully maintained at $-20^{\circ} \mathrm{C}$ during the required etching time to achieve the desired 
geometry. This time varies with the chosen geometry and the substrate doping concentration. In earlier work [4-6], we masked the surface with photoresist stripes to define the axes of the grooves. For doping concentrations less than $1 \mathrm{E} 18 \mathrm{~cm}^{-3}$, a complete sawtooth structure of 8 micron periodicity takes approximately six minutes. The planes revealed by the etching are (111) In surfaces when the photoresist stripes are aligned along the [01T] direction.

\section{Table 1}

\section{Lewis Etchant}

\begin{tabular}{ccc} 
Component & Assay & Ratio \\
\hline $\mathrm{HBr}$ & $49 \%$ in $\mathrm{H}_{2} \mathrm{O}$ & 10 \\
$\mathrm{H}_{2} \mathrm{O}_{2}$ & $31 \%$ in $\mathrm{H}_{2} \mathrm{O}$ & 1 \\
$\mathrm{HCl}$ & $38 \%$ in $\mathrm{H}_{2} \mathrm{O}$ & 1
\end{tabular}

Temperature: held constant at $-20^{\circ} \mathrm{C}$

\section{UNMASKED V-GROOVES}

The requirement for photoresist stripes adds an additional step in fabrication. In order to reduce the additional cost and process complexity for fabrication of electronic devices, it is desirable to develop processes for texture etches to low surface reflection without this photoresist step.

One such process, discussed by Jenkins and Landis, produces low-angle V-grooves using a $\mathrm{HCl}$ etch at $17^{\circ} \mathrm{C}$ in room light [7]. The groove surfaces are roughly (311) crystal planes. These low-angle $\mathrm{V}$-grooves can also be used to decrease the surface reflectivity in solar cells which include a glass cover by the effect of total internal reflection at the air/coverglass interface [8].

Based on the successful etching of low-angle grooves in InP without a photoresist mask, we investigated whether the Lewis etchant could be used to produce high-angle grooves by etching the surface without a photoresist mask.

In the current work, Lewis etch at $-20^{\circ} \mathrm{C}$ was used to etch the surface of (100) InP samples of various doping type and concentration. Unless specified, etching was done under ambient room light. InP wafers used had an initially polished surface.

The surface structures formed by the etch were found to be strongly dependent on the etch time and the dopant concentration.

Figures 1 and 2 show a scanning electron micrograph of the surface of highly doped p-type ( $\mathrm{Zn:} 2.8 \mathrm{E} 18 \mathrm{~cm}^{-2}$ ) InP wafers after 30 seconds, and after four minutes, of etching. In 30 seconds, ridges defined by intersections of the (111)In plane are beginning to emerge from the etch. After an etch of 4 minutes, these ridges form $V$-grooves over much of the wafer.

Further tests were done with etch durations of 30 seconds (except where noted) to study the initiation of the grooving process. The short etch duration has the disadvantage that the etch is more sensitive to impurities on the surface, and is not always completely uniform across the wafer surface. The longer etch times had much greater surface uniformity.

Figures 3 and 4 show low and high magnification views of a p-type $\left(\mathrm{Zn}: 1.5 \mathrm{E} 18 \mathrm{~cm}^{-2}\right) \mathrm{InP}$ wafer after 30 seconds of etching. The sample is rotated $90^{\circ}$ between the two photographs to show views parallel and perpendicular to the [110] direction on the surface. The anisotropy of 
the etching is clearly visible; even in only 30 seconds, the surface has formed irregular, but clearly visible, ridges running generally along the [1T0] direction.

Figure 5 and 6 show samples of slightly lower doping ( $\mathrm{Zn}: 2 \mathrm{E} 16 \mathrm{~cm}^{-2}$ ), etched for 30 seconds and for one minute. The etch is slower at the lower doping. At thirty seconds the surface shows irregular bumps, slightly elongated along the [110] direction. At one minute the surface is covered with pyramids with clearly defined planar facets, with the pyramids forming roughly in lines along the [1T0]. Figure 7 is a cleaved edge of the sample, showing a crosssection through the peaks. The etched surfaces are (111) planes.

Figure 8 shows a sample of an order of magnitude lower doping ( $\mathrm{Zn}: 2 \mathrm{E} 15 \mathrm{~cm}^{-2}$ ), etched for four minutes. For this etching condition, the grooves are rounded, showing an apparently much lower degree of anisotropy of the etch.

Maskless V-grooves form more easily on n-type InP than on p-type. Figures 9 and 10 show a n-type wafer of moderate doping (S: $4 \mathrm{E} 17 \mathrm{~cm}^{-2}$ ) after 30 seconds of etching, showing clear grooves. V-grooves are not always immediately formed. A different sample of the same doping, etched under the same nominal conditions, is shown in figure 11. On this sample grooves have not been formed over most of the surface; however, in regions of the sample in close proximity to photoresist patterning (not shown), the etch depth was slightly greater and grooves formed. This indicates that groove formation would likely be completed under slightly higher concentration, or longer etch times, for this sample as well.

Figure 12 shows a wafer of lower doping (S: $\left.4 \mathrm{E} 15 \mathrm{~cm}^{-2}\right)$ under the same etch conditions. Clear grooves are beginning to form. Wafers of intermediate doping ( $\left.\mathrm{S}: 3 \mathrm{E} 16 \mathrm{~cm}^{-2}\right)$ show essentially identical groove formation.

Preliminary measurements of light reflection from the surface have been made, showing reduced reflectivity from the grooved surface. This work is continuing.

\section{CONCLUSIONS}

Maskless etching was found to produce irregular ridges or V-grooves on the surface of (100) InP wafers. The etch rate and surface texture produced were found to be strongly dependent on the etch time and sample doping.

In all cases where etching proceeded to groove formation, the groove axes are irregular, but generally along the [1T0] direction. Grooves on the front surface of the wafer are perpendicular to grooves formed on the rear. The groove dimensions are extremely fine, with groove spacing on the order of one micron. The finest groove spacing, on the order of the wavelength of visible light, results in visible diffraction of white light.

The etching shows a clear tendency to proceed faster, and with a higher degree of anisotropy, on material of higher doping; with n-type InP etching into grooves more easily than p-type. Increasing the etch temperature to $0^{\circ}$ decreases the anisotropy observed. The process does not require photolithography or masking. Reduced reflectivity surfaces formed using this process can be applied to solar cells, photodetectors, and other optoelectronic devices.

\section{REFERENCES}

1. J. Haynos, J. Allison, R. Arndt, and A. Meulenberg, "The COMSAT Non-reflective Silicon Solar Cell," Proc. Int. Conf. on Photovoltaic Power Generation, Sept. 1974, pp. 487501. 
2. S.G. Bailey, N. Fatemi, D.M. Wilt, R.D. Thomas, G.A. Landis, and A. Arrison, Conference Record of the 20th IEEE Photovoltaic Specialists Conf. (IEEE, NY, 1988), pp. $625-628$.

3. S.G. Bailey, G.A. Landis, and D. M. Wilt, J. Electrochem. Soc., Vol 136, No. 11, Nov. 1989, pp. 3444-3449.

4. S.G. Bailey, N. Fatemi, and M. Faur, Proc. 2nd International Conf. on InP and Related Compounds, (1990), pp. 73-79.

5. S.G. Bailey, N. Fatemi, and G.A. Landis, Conference Record of the 22nd IEEE Photovoltaic Specialists Conf. (IEEE, NY, 1991), pp. 235-240.

6. S.G. Bailey, N.S. Fatemi, G.A. Landis and P.P. Jenkins, Space Photovoltaic Research and Technology 1991 (NASA Lewis Research Center CP-3121, 1991), pp. 5-1 to 5-6.

7. P. Jenkins and G.A. Landis, Proc. 3rd International Conf. on InP and Related Compounds, (1991), pp. 636-639; P. Jenkins, G.A. Landis, X. Li, D. Scheiman, N. Fatemi and S.G. Bailey, 4th International Conf. on InP and Related Compounds (1992).

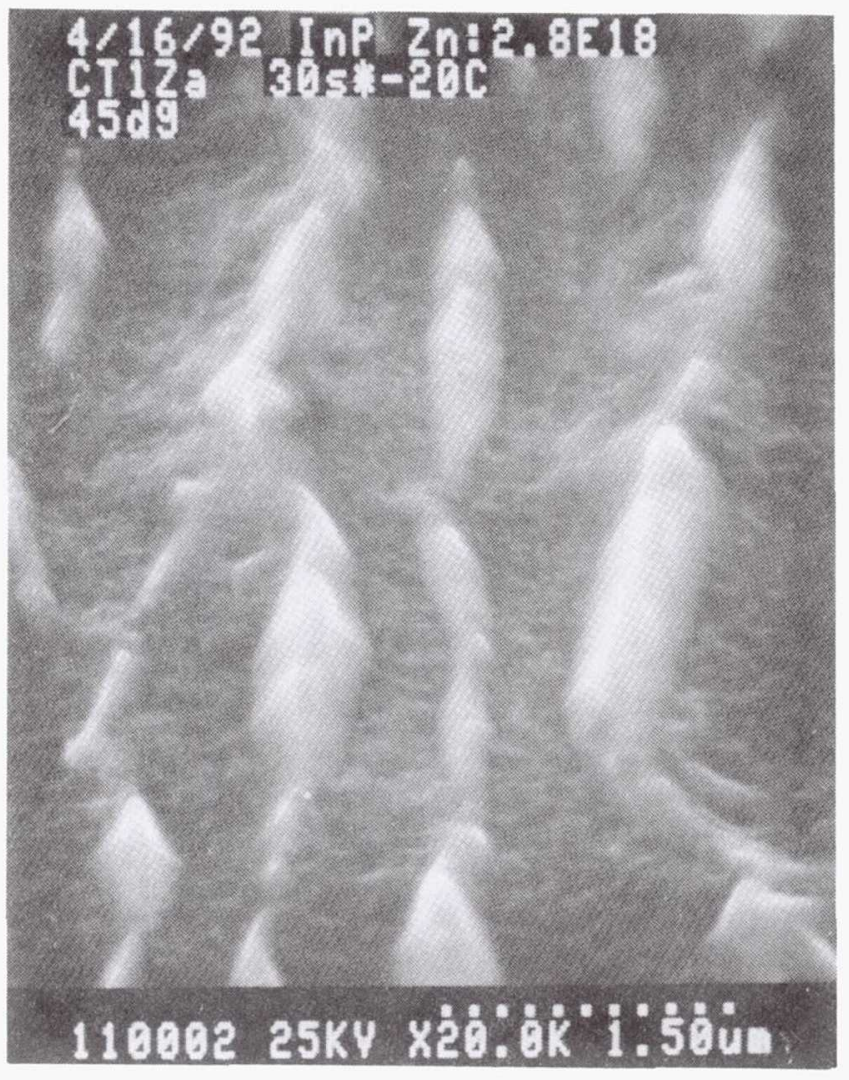

Figure 1.-p-InP: Zn2.8E18 etched $.5 \mathrm{~min}$.

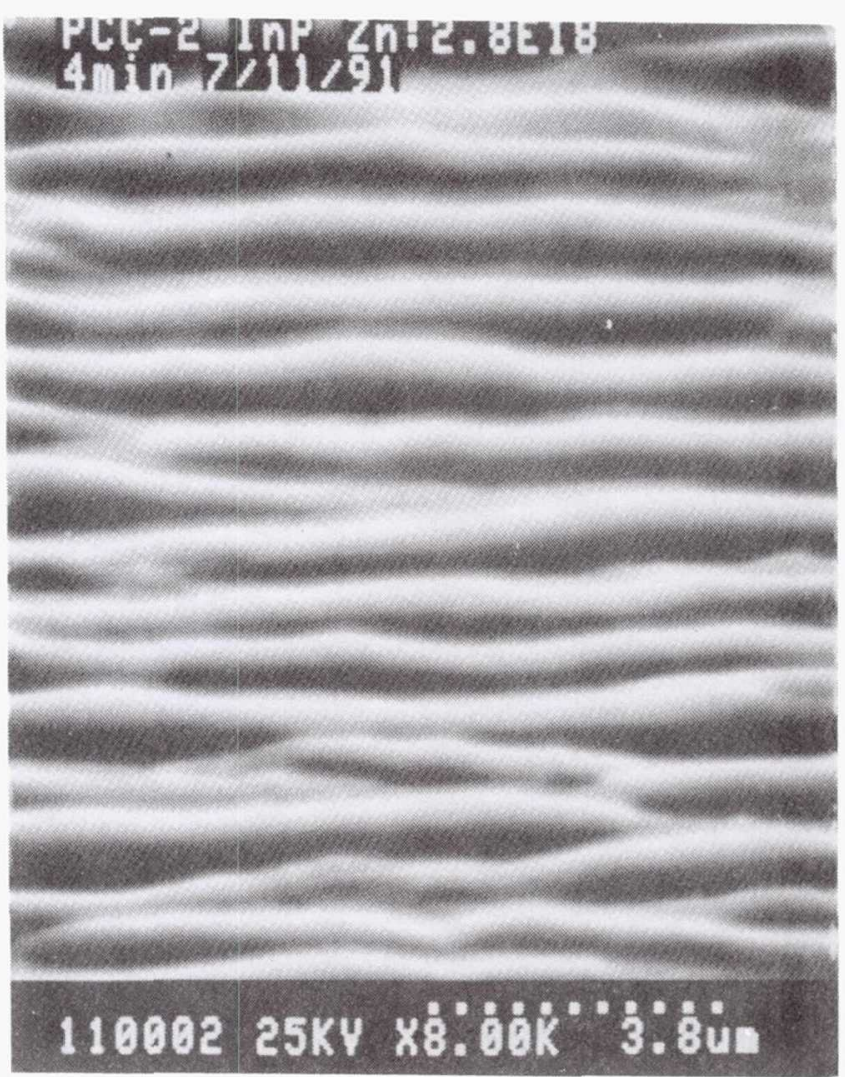

Figure 2.-p-InP: Zn:2.8E18 etched $4 \mathrm{~min}$. 


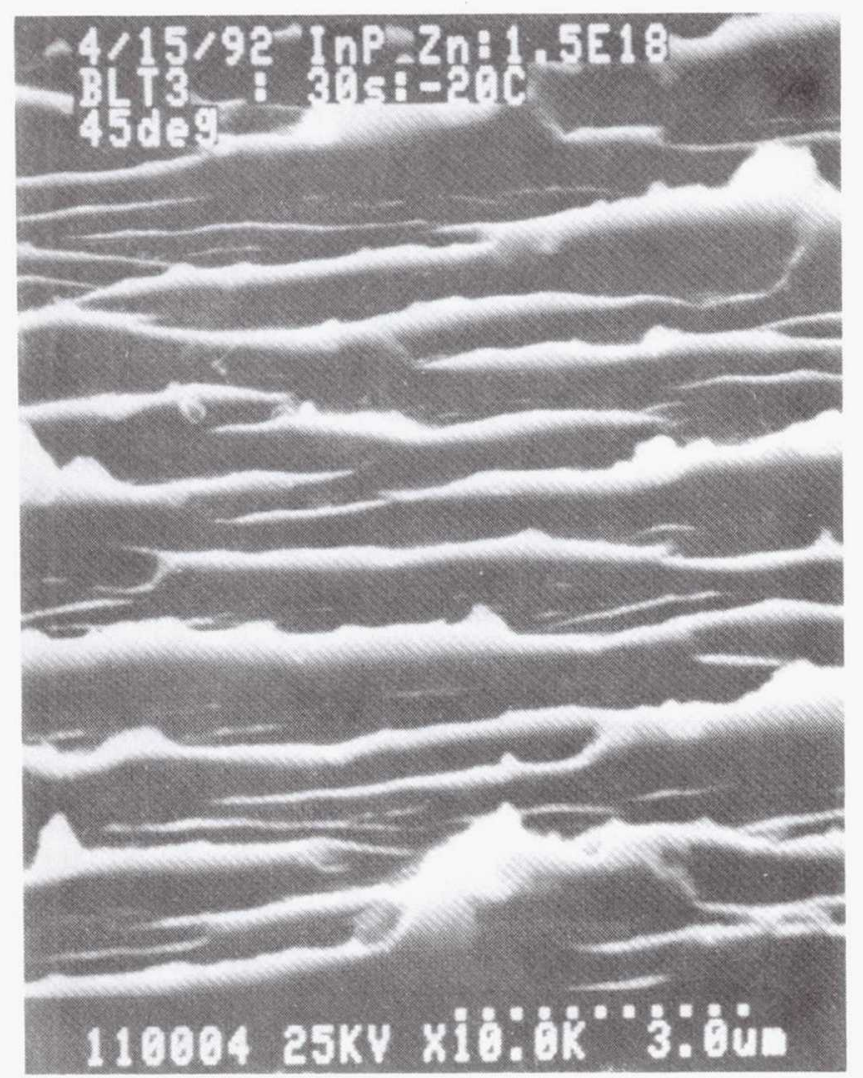

Figure 3.-p-InP: Zn:1.5E18 etched $.5 \mathrm{~min}$.

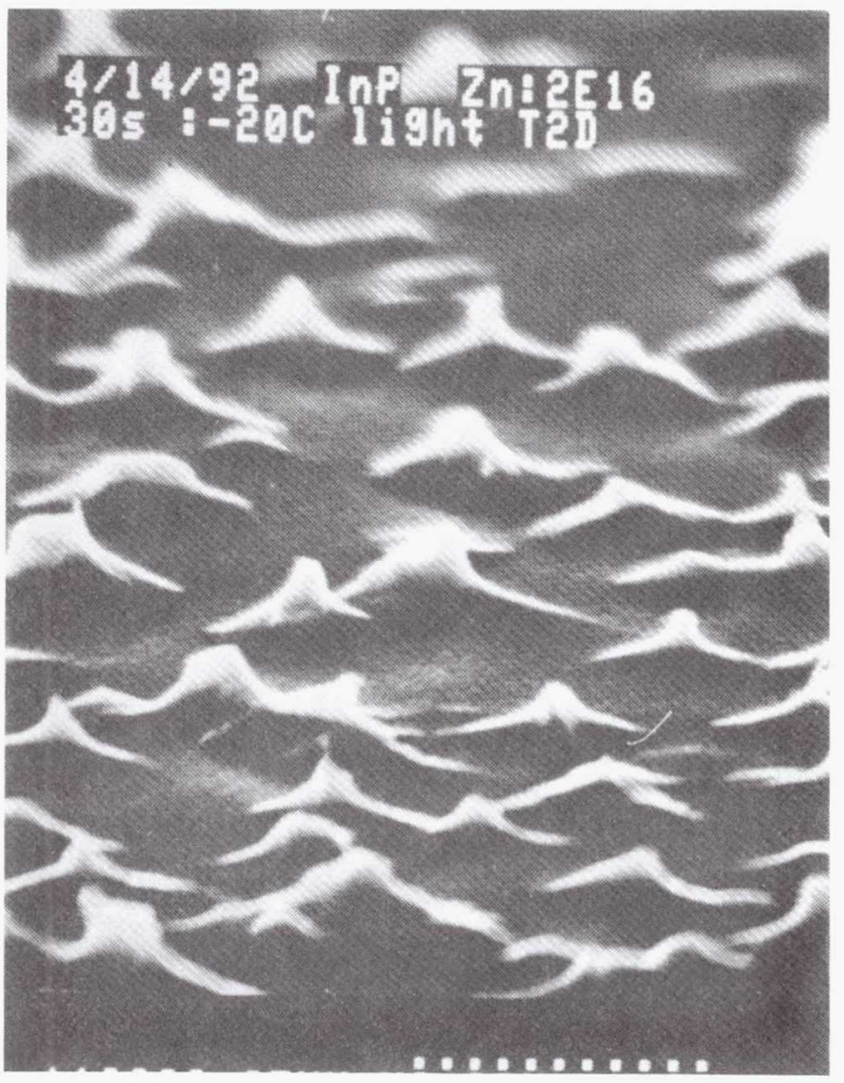

Figure 5.-p-InP: Zn:2E16 etched $.5 \mathrm{~min}$.

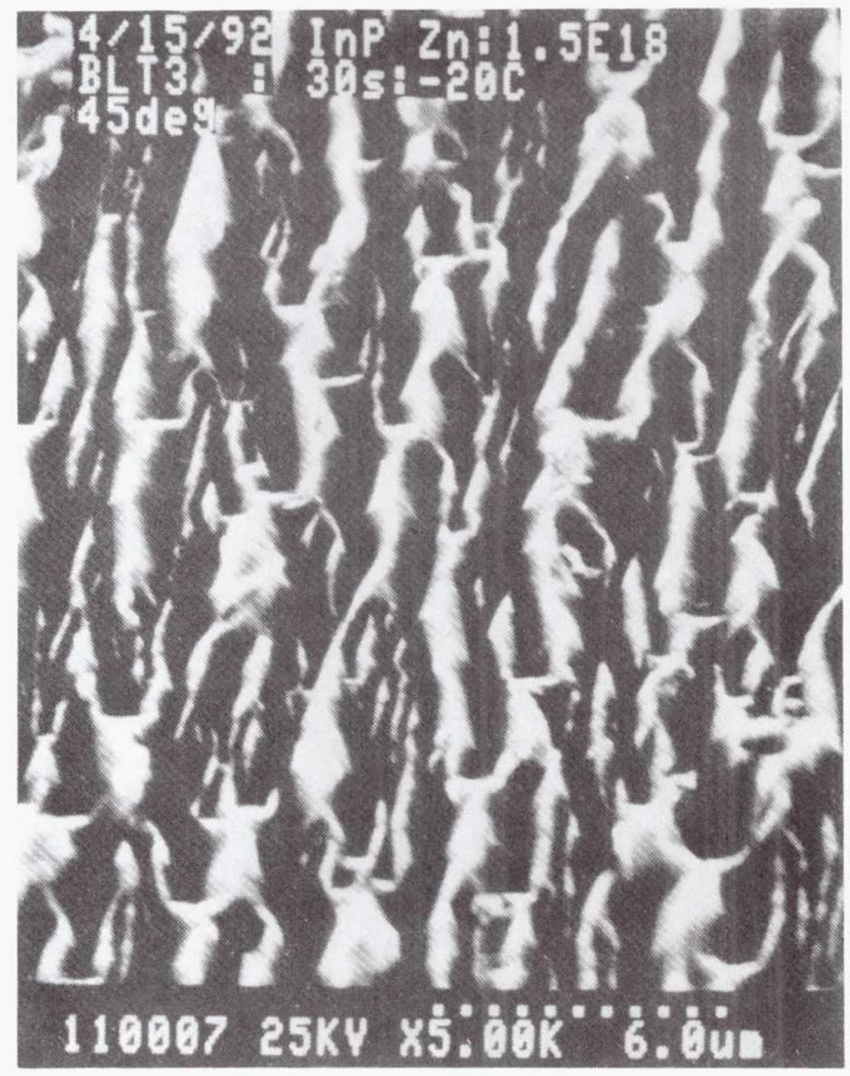

Figure 4.-p-InP: Zn:1.5E18 etched $.5 \mathrm{~min}$. (rotated)

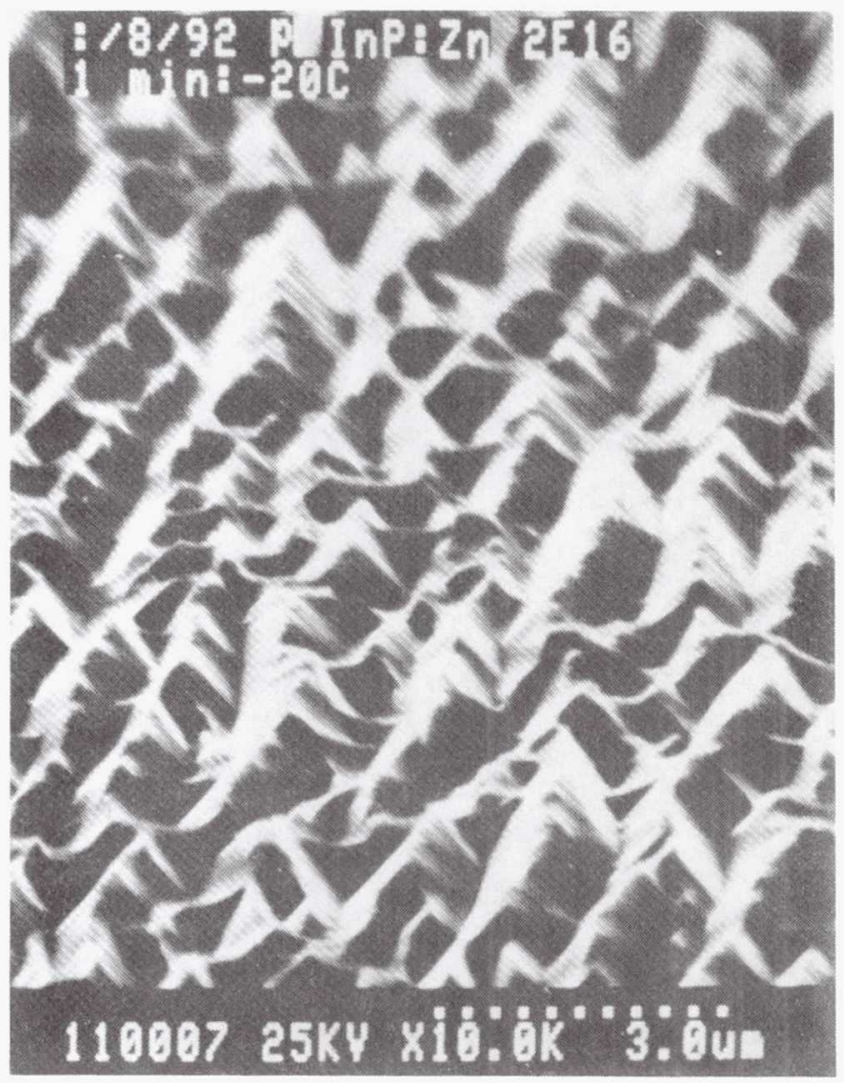

Figure 6.-p-InP: Zn:2E16 etched $1 \mathrm{~min}$. 


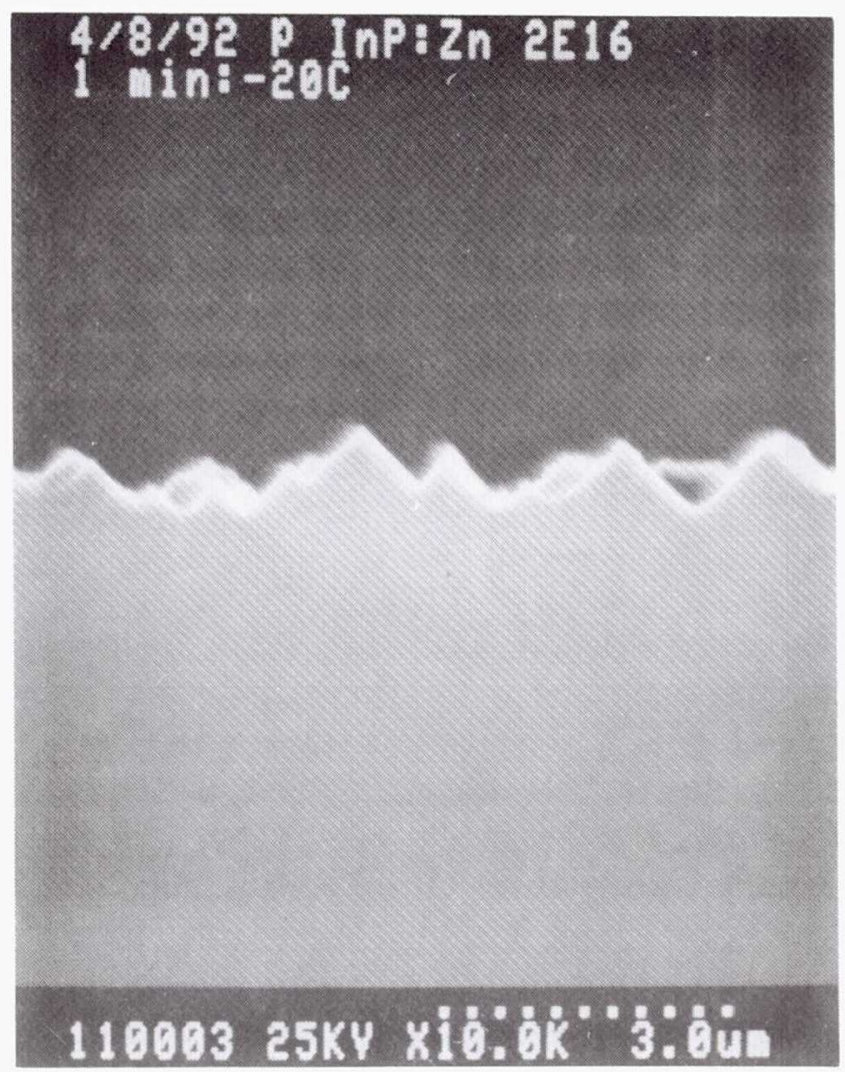

Figure 7.-p-InP: Zn:2E16 etched $1 \mathrm{~min}$.

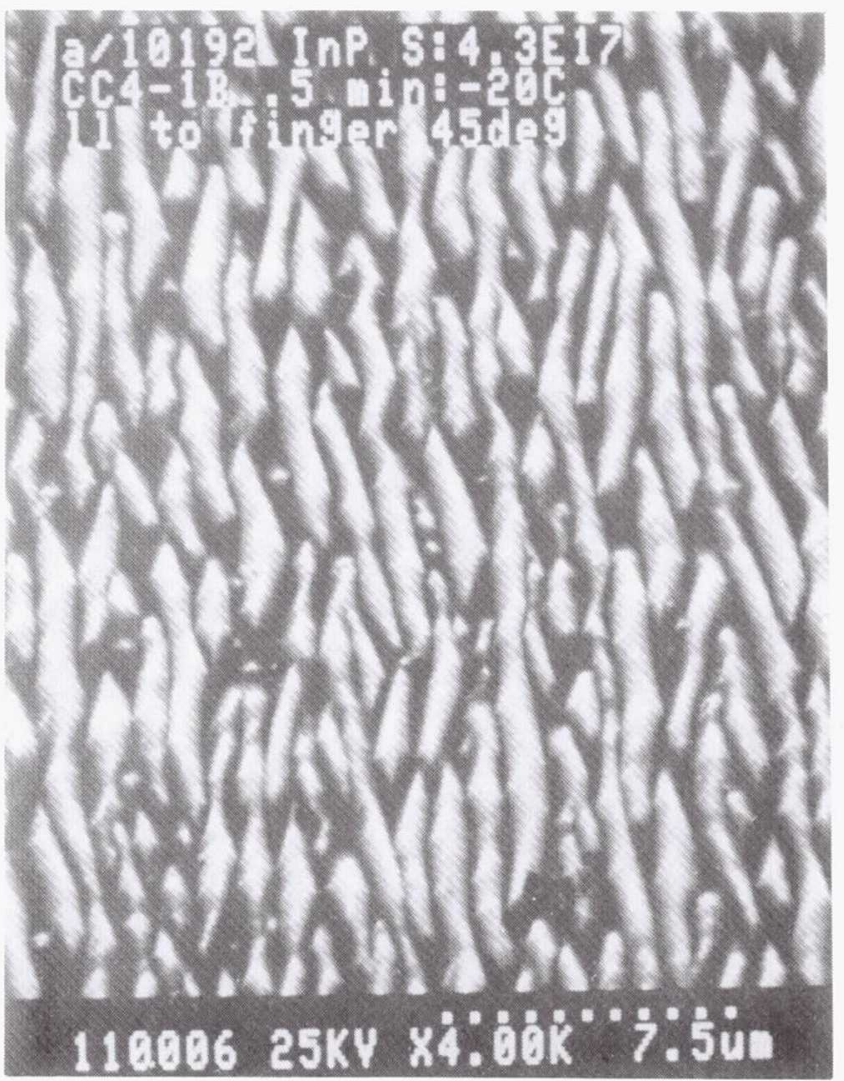

Figure 9.-n-InP: S:4.3E17 etched $.5 \mathrm{~min}$.

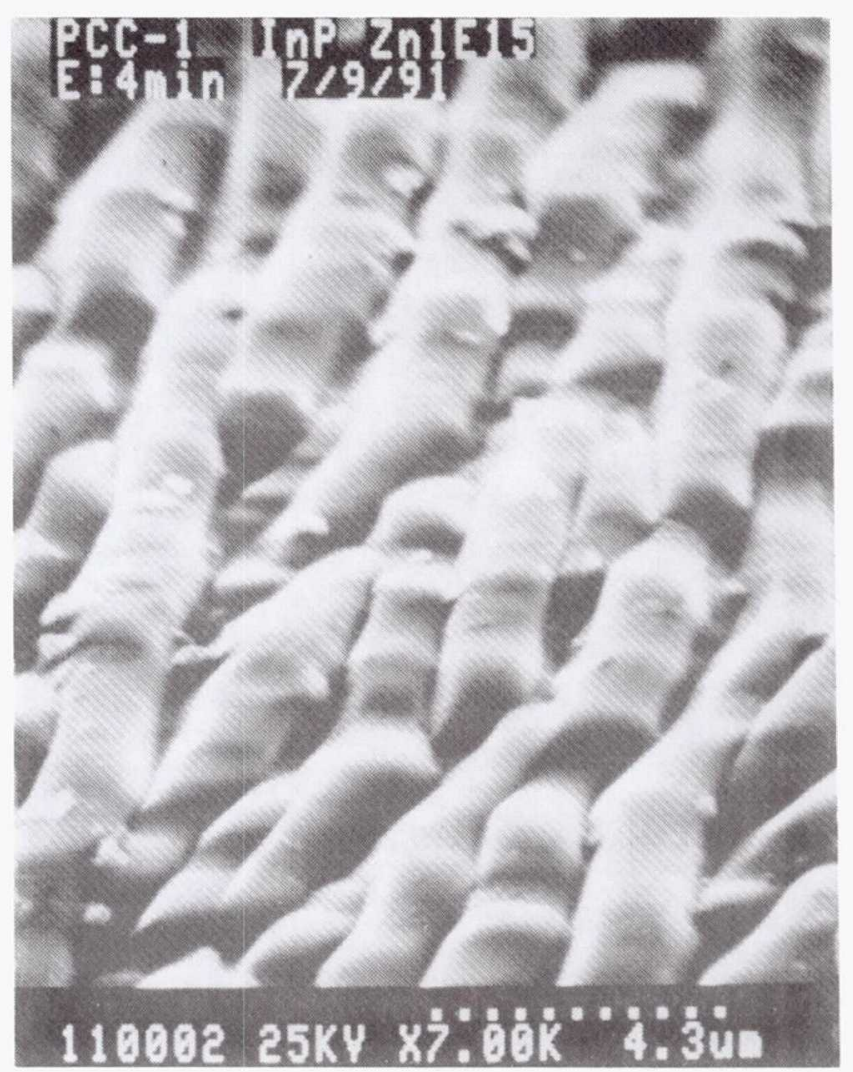

Figure 8.-p-InP: Zn:1E15 etched $4 \mathrm{~min}$.

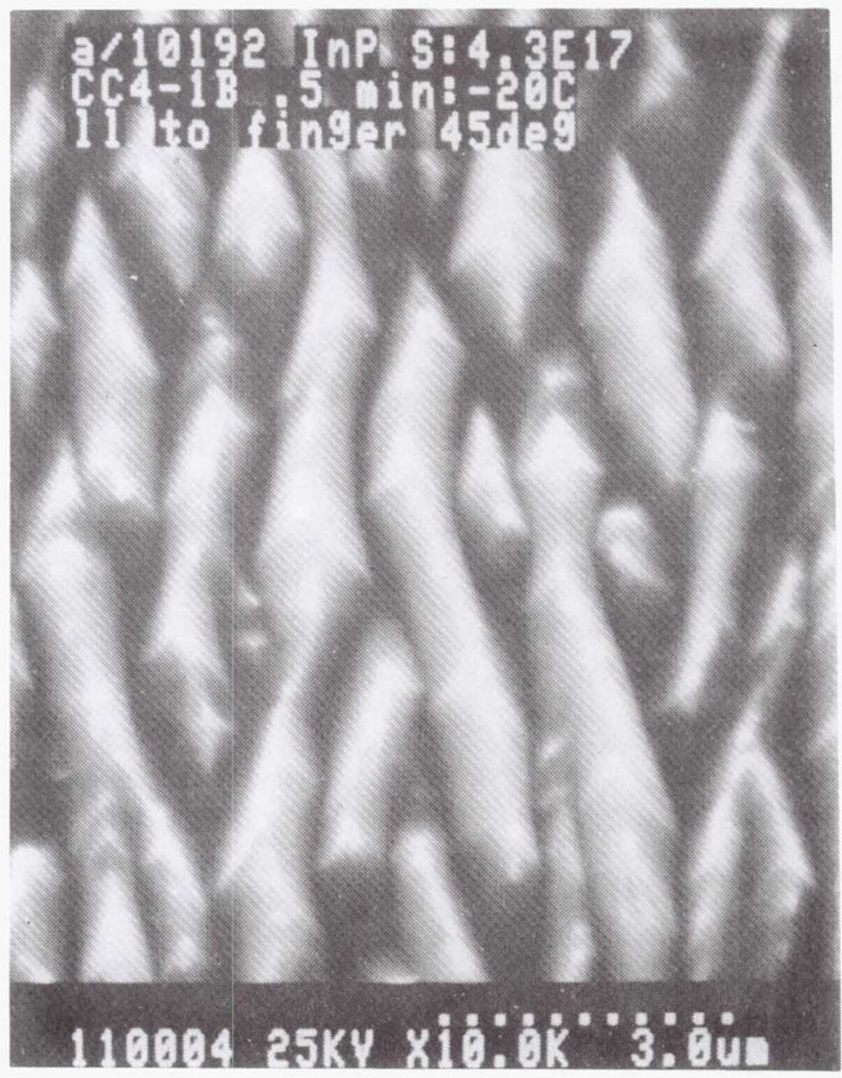

Figure 10.-n-InP: S:4.3E17 etched $.5 \mathrm{~min}$. 


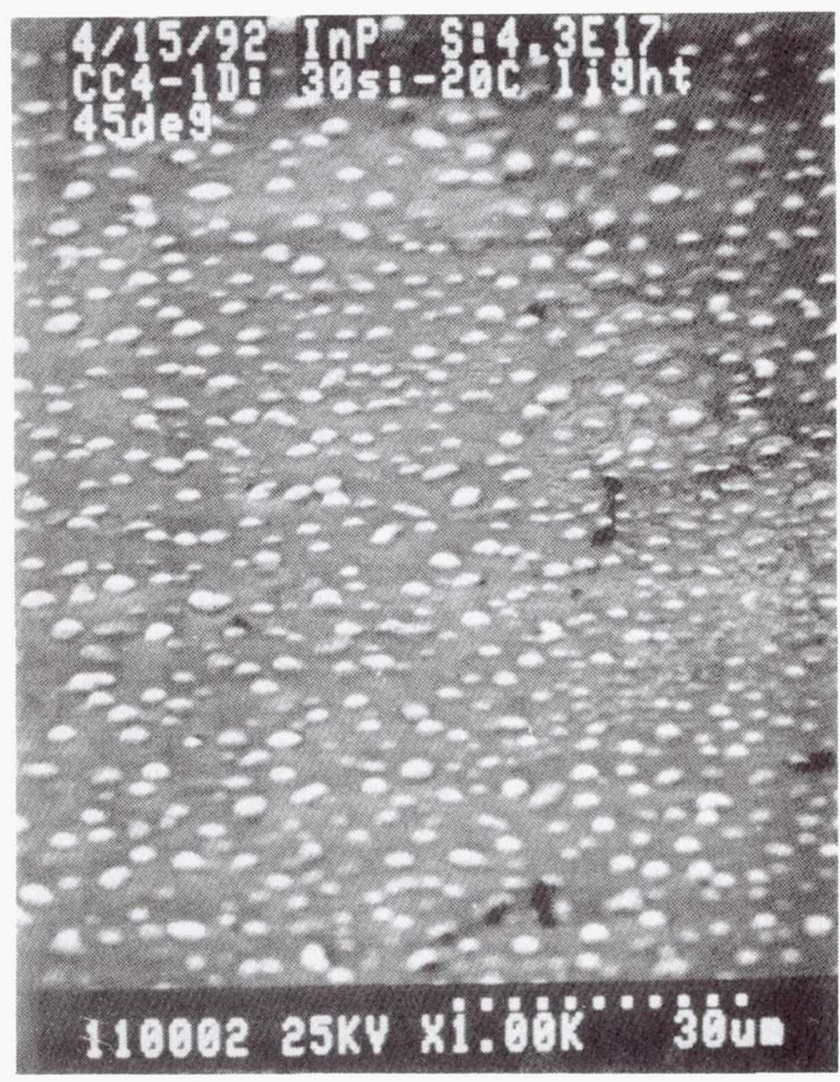

Figure 11. $-n-\operatorname{InP}:$ S:4.3E17 etched $.5 \mathrm{~min}$.

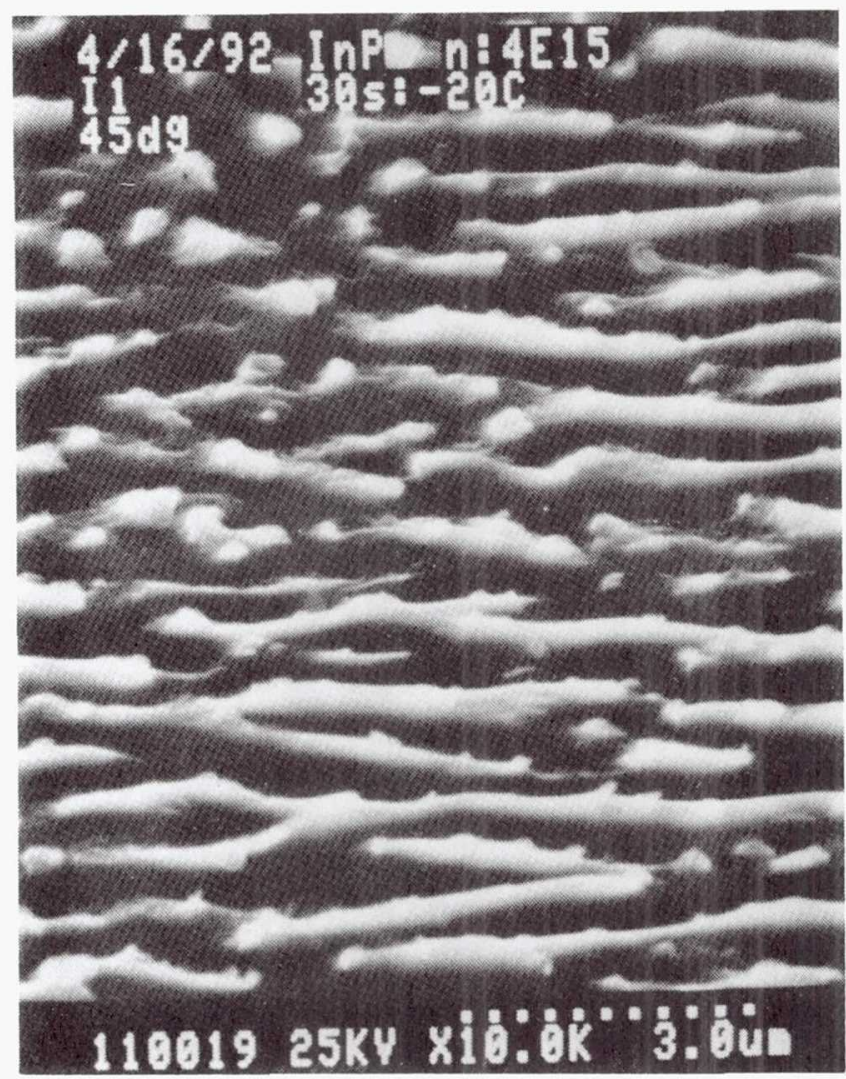

Figure 12. $-n-\ln P: S: 4 E 15$ etched $.5 \mathrm{~min}$. 
Public reporting burden for this collection of information is estimated to average 1 hour per response, including the time for reviewing instructions, searching existing data sources, gathering and maintaining the data needed, and completing and reviewing the collection of information. Send comments regarding this burden estimate or any other aspect of this Davis Highway, Suite 1204, Arlington, VA 22202-4302, and to the Office of Management and Budget, Paperwork Reduction Project (0704-0188), Washington, DC 20503.

\begin{tabular}{|l|l|l|}
\hline 1. AGENCY USE ONLY (Leave blank) & $\begin{array}{c}\text { 2. REPORT DATE } \\
\text { April } 1992\end{array}$ & $\begin{array}{r}\text { 3. REPORT TYPE AND DATES COVERED } \\
\text { Technical Memorandum }\end{array}$ \\
\hline
\end{tabular}

4. TITLE AND SUBTITLE

Texturing of InP Surfaces for Device Applications

6. AUTHOR(S)

Sheila G. Bailey, Navid S. Fatemi, and Geoffrey A. Landis
5. FUNDING NUMBERS

WU-506-41-11

\section{PERFORMING ORGANIZATION NAME(S) AND ADDRESS(ES)}

National Aeronautics and Space Administration

Lewis Research Center

Cleveland, Ohio 44135-3191
8. PERFORMING ORGANIZATION REPORT NUMBER

E-7664

\section{SPONSORING/MONITORING AGENCY NAMES(S) AND ADDRESS(ES)}

National Aeronautics and Space Administration

Washington, D.C. 20546-0001
10. SPONSORING/MONITORING AGENCY REPORT NUMBER

NASA TM-106061

\section{SUPPLEMENTARY NOTES}

Prepared for the 1992 Spring Meeting of the Materials Research Society sponsored by the Materials Research Society, San Francisco, California, April 27-May 1, 1992. Sheila G. Bailey, NASA Lewis Research Center. Navid S. Fatemi and Geoffrey A. Landis, Sverdrup Technology, Inc., Lewis Research Center Group, 2001 Aerospace Parkway, Brook Park, Ohio 44142. Responsible person, Sheila Bailey, (216) $433-2228$.

12a. DISTRIBUTION/AVAILABILITY STATEMENT

12b. DISTRIBUTION CODE

Unclassified - Unlimited

Subject Category 26

13. ABSTRACT (Maximum 200 words)

A unique process for texturing InP (100) wafers by anisotropic etching has been developed. The process produces irregular V-grooves on the surface, which reduce the surface reflectivity. The process does not require photolithography or masking. The etching characteristics depend on doping, with etching tending to proceed more rapidly on the more heavily doped samples. Reduced reflectivity surfaces formed using this process can be applied to solar cells, photodetectors, and other optoelectronic devices.

\begin{tabular}{|c|c|}
\hline 14. SUBJECT TERMS \\
Indium phosphide; Solar cell; Etching; Light trapping \\
\hline $\begin{array}{l}\text { 17. SECURITY CLASSIFICATION } \\
\text { OF REPORT } \\
\text { Unclassified }\end{array}$ & $\begin{array}{c}\text { 18. SECURITY CLASSIFICATION } \\
\text { OF THIS PAGE } \\
\text { Unclassified }\end{array}$ \\
\hline
\end{tabular}

\begin{tabular}{|l|c|}
\hline & $\begin{array}{c}\text { 15. NUMBER OF PAGES } \\
9\end{array}$ \\
\cline { 2 - 3 } & 16. PRICE CODE \\
A02
\end{tabular}

